\title{
RESENHAS RESENHAS RESENHAS RESENHAS
}

https://doi.org/10.1590/198053146110

\section{UMA REFERÊNCIA OBRIGATÓRIA NA ÁREA DA HISTÓRIA DA EDUCAÇÃO}

\author{
Dagmar M. L. Zibas'
}

PALMA FILHO, João Cardoso. Política educacional brasileira: educação brasileira numa década de incerteza (1990-2000): avanços e retrocessos. 2. ed. São Paulo: Porto de Ideias, 2018.

A notável trajetória profissional do autor, abrangendo atividades de pesquisa, docência e administração de políticas educacionais, todas exercidas com reconhecidas competência e seriedade, faz com que a $2^{\mathrm{a}}$ edição do livro em foco renove sua condição de referência obrigatória para os estudiosos da educação brasileira.

O período pesquisado - os anos 1990 - é outra característica que torna este trabalho do prof. Palma uma fonte valiosa para os analistas de nossa história educacional.

Embora se detenha também nas políticas das administrações de Collor e Itamar, são as iniciativas dos dois governos de Fernando Henrique Cardoso (FHC) que merecem maior aprofundamento no estudo. Essa opção é natural não só pela maior extensão do mandato de FHC, mas também por duas características importantes dos dispositivos legais implementados: coerência político-ideológica e firmeza nos objetivos.

De fato, como bem nota o autor e como ressalta Maria Leila Alves, no Prefácio, as diretivas para a educação do governo FHC aderiram à hegemonia do pensamento neoliberal do período, adaptando ao país as políticas idealizadas pelas agências internacionais e contando, para isso, com vultuoso empréstimo do Banco Mundial.

A Lei de Diretrizes e Bases da Educação Nacional (LDB), de 1996, foi promulgada depois de um duro embate, tanto na área acadêmica quanto na arena política, prevalecendo a orientação governamental de conformidade às tendências ideológicas predominantes nos anos 1990. Castro e Tiezzi (2005, p. 126), ambos da equipe do Ministério da Educação na ocasião, embora não especifiquem, como faz o livro, a raiz ideológica da reforma, reconhecem sua adesão à corrente hegemônica:

[...] a matriz de inspiração da reforma brasileira, concretizada por meio da nova LDB, de 20 de dezembro de 1996, e nos decretos posteriores, foi o novo paradigma educacional 
que passou a orientar a maioria das reformas educativas de ensino médio e profissional no mundo durante os anos 1990.

O escrutínio dos documentos oficiais e a exaustiva discussão da bibliografia crítica, como elaborados por Palma Filho, permitem que se desvendem os meandros técnicos e políticos das inovações introduzidas, inclusive mostrando a gênese das escolhas que se consolidaram na promulgação da LDB.

Ao analisar o Planejamento Estratégico do primeiro governo FHC, que trouxe um diagnóstico dos problemas de todos os níveis de ensino e embasou as profundas mudanças aplicadas a todo o sistema, o autor aponta seus desdobramentos. Por exemplo, são descritas as polêmicas suscitadas pelas novas Diretrizes Curriculares e pelos novos Parâmetros Curriculares Nacionais. Sobre o currículo organizado em torno do desenvolvimento de competências, a conclusão de Palma Filho tornou-se consensual no mundo acadêmico: essa iniciativa não poderia ser bem-sucedida junto a professores, uma vez que estes pensam normalmente em termos de conteúdos de aprendizagem. O tempo deu razão aos críticos.

Mesmo com todas as ressalvas, os Parâmetros Curriculares Nacionais possibilitaram a introdução do Sistema de Avaliação da Educação Básica, que constituía a exigência central do financiamento externo. Teoricamente, uma aferição, de abrangência nacional, dos resultados da aprendizagem pode ser um instrumento moderno e eficaz para orientação de políticas. Essa reconhecida qualidade da avaliação sistêmica sustentou a vigência desse instrumental até hoje. No entanto, as críticas iniciais também são pertinentes atualmente. Uma delas é a de que a responsabilização das escolas e/ou das instâncias estaduais e municipais, sem qualquer garantia de que disponham de recursos técnicos e materiais para atingir os objetivos propostos, poderia (e pode) dar origem a fraudes de diversos tipos (recentemente, acusações nesse sentido, veiculadas pela grande mídia, têm nublado os excelentes resultados que as escolas cearenses vêm alcançado nas avaliações nacionais ${ }^{1}$ ).

O autor traz números, referentes à década de 1990, que atestam o avanço significativo das matrículas no ensino básico e a correção de seu fluxo, com a diminuição da evasão e da repetência. Todavia, a análise também aponta a transformação da virtuosa progressão continuada em perversa promoção automática, sem qualquer progresso na aprendizagem. Mais uma vez, os parcos recursos disponíveis nas escolas são responsáveis pela farsa instalada. O texto ainda destaca que, no período estudado, a prioridade concedida ao ensino básico teve como contraponto o encolhimento da oferta de vagas nas universidades federais, com o veto à ampliação e à interiorização das unidades mantidas pela União.

A notável expansão do ensino médio, durante os anos 1990, também é registrada no livro, que anota ainda a crítica à reforma que, em 1997, instituiu 
estruturas paralelas nesse nível de ensino, permitindo que a formação técnica, organizada em módulos, fosse oferecida separadamente do ensino médio regular. Essa dualidade estrutural foi justificada de diversas maneiras, mas, para os críticos, a mudança apenas reforçava a clivagem social de classes, que destinaria o ensino regular àqueles que se encaminhariam à universidade, reservando aos trabalhadores apenas um ensino profissional estreito e terminal.

O estudo é minucioso ao traçar o histórico da legislação que enfoca a formação de professores e detalha as polêmicas que envolveram a interpretação de artigos da LDB que tratam de tal tema. A conclusão é pessimista: a dificuldade para formação dos profissionais da educação não está nos princípios técnicos e éticos exigidos, que são consensuais, mas sim nas instâncias formadoras, pois as instituições particulares procuram menores custos e maior rentabilidade, enquanto as universidades públicas consideram as licenciaturas adendos de segundo plano. Sabe-se que tal fragilidade permanece hoje, ampliada pelo crescente desinteresse dos egressos do ensino médio pela carreira do magistério.

Enfim, o autor traça um painel muito claro e detalhado das políticas para educação dos anos 1990, descrevendo e quantificando os avanços, apontando os impasses e retrocessos e deslindando a trama política e ideológica que orientou as inovações implantadas.

Tal análise é de muita relevância para estudiosos da área, principalmente neste momento crucial de nossa democracia, quando, de qualquer forma, o governo recém-empossado deverá ser instado a continuar os avanços alcançados e a evitar a repetição dos graves erros que têm travado nosso desenvolvimento na área da educação.

As palavras de Palma Filho (2018, p. 177) que fecham o texto são desafiadoras por seu duplo sentido: apontam a crueza e a rigidez de uma estrutura socioeconômica injusta que obstaculiza o avanço educacional, mas também insinuam que há brechas para a luta pela utopia de uma educação emancipadora:

É importante termos as nossas utopias, mas não ilusões... estamos diante de um Estado de classes, onde, portanto, o mais importante é garantir, custe o que custar, a acumulação capitalista, mesmo que seja com o sacrifício das políticas sociais.

\section{REFERÊNCIAS}

CASTRO, M. H. G.; TIEZZI, S. A reforma do ensino médio e a implantação do Enem no Brasil. In: BROCK, C.; SCHWARTZMAN, S. (org.). Os desafios da educação no Brasil. Rio de Janeiro: Nova Fronteira, 2005. p. 119-154. 
COMO CITAR ESTA RESENHA:

ZIBAS, Dagmar M. L. Uma referência obrigatória na área da história da educação. Cadernos de Pesquisa, São Paulo, v. 49, n. 171, p. 338-341, jan./mar. 2019. [Seção] Resenhas. Resenha da obra de: PALMA FILHO, João Cardoso. Política educacional brasileira: educação brasileira numa década de incerteza (1990-2000): avanços e retrocessos. 2. ed. São Paulo: Porto de Ideias, 2018. https://doi.org/10.1590/198053146110. 